\title{
Determination of Metformin. HCL in Pharmaceutical Formulations, Environmental Water Samples
}

\author{
Nief Rahman Ahmed* \\ Department of Environmental Technology, College of Environment, University of Mosul, Iraq \\ *Corresponding author: Nief Rahman Ahmed, Department of Environmental Technology, College of Environment, \\ University of Mosul, Iraq
}

\section{ARTICLE INFO}

Received: 櫘 September 05, 2020

Published: 慧 September 16, 2020

Citation: Nief Rahman Ahmed. Determination of Metformin. HCL in Pharmaceutical Formulations, Environmental Water Samples. Biomed J Sci \& Tech Res 30(3)-2020. BJSTR. MS.ID.004959.

ABSTRACT

A simple, accurate, precise, rapid, economical and sensitive ultraviolet spectrophotometric method has been developed for the estimation of metformin hydrochloride in pharmaceutical preparations and environmental wastewater samples, which shows maximum absorbance at $232 \mathrm{~nm}$ in distilled water. Beer's law was obeyed in the range of $2-16 \mu \mathrm{g} / \mathrm{ml}$, with molar absorptivity of $1.28 \times 104$ L.mol-1.cm-1, relative standard deviation of the method was less than 1.8\%, and accuracy (average recovery $\%$ ) was $100 \pm 1.0$.The method was successfully applied to the estimation of metformin hydrochloride in pharmaceutical formulations (tablets),environmental water samples and content uniformity testing. The proposed method was validated by sensitivity and precision which proves suitability for the routine analysis of metformin hydrochloride in true samples.
\end{abstract}

Keywords: Metformin Hydrochloride, Estimation; Pharmaceutical Preparations;Content Uniformity

\section{Introduction}<smiles>CN(C)C(=N)NC(=N)N</smiles>

Figure 1: Chemical structure of metformin hydrochloride Metformin Hydrochloride (C4H11N5.Hcl) M. Wt. = 165.6

Metformin hydrochloride is an oral anti hyperglycemic agent used to lower blood glucose in patients suffering from diabetes of non-insulin dependent. Metformin hydrochloride (Glucophage) [1], chemically is known as 1,1-Dimethyl biguanide hydrochloride with a molecular formula of $\mathrm{C} 4 \mathrm{H} 12 \mathrm{Cl}$ N5 (Figure 1). It is an oral ant diabetic drug that has been used in the treatment of non- insulin dependent diabetes which improves control of glycemia primarily by inhibiting hepatic gluconeogenesis and glucogenolysis[2] and seems to ameliorate hyperglycemia by improving peripheral sensitivity to insulin, reducing gastrointestinal glucose absorption and hepatic glucose production. Recently, metformin has also become available for the treatment of polycystic ovary syndrome and has been found to improve vascular function, prevent pancreaticcancer and revers fatty liver diseases [1-4].

Analytical procedures for the estimation of metformin hydrochloride include non-aqueous potentiometric titrimetric method [5], various spectrophotometric methods [6,7], HPLC [8,9], Another different methods for the determination of metformin have been described, such as conduct metric titration10, flowinjection chemiluminescence[11-13], capillary electrophoresis[14], ion-selective electrode[15] and adsorptivecatalytic squarewave voltammetry[16] However, all of these methods suffered from several disadvantages including tedious,time consuming, ultra-filtration and column-switching technique which required expensive or sophisticated instruments and not simple for routine analysis. The proposed method reports the development of a new 
UV method and can be applicable to routine analysis and content uniformity test of metformin hydrochloride in tablets and complies well with the validation requirements in the pharmaceutical industry[17].

\section{Experimental}

\section{Apparatus}

Shimadzu UV- 1700 pharm aspect (double beam) spectrophotometer with $1.0 \mathrm{~cm}$ quartz cells was used for absorption measurement.

\section{Reagents}

All chemical used were of analytical or pharmaceutical grade and metformin. hydrochloride standard material and pharmaceutical preparations (tablets) was provided from state company of drug industries and medical appliance (NDI) Nineveh - Iraq. Distilled water was used as a solvent.

\section{Metformin Hydrochloride Standard Solution 100ppm}

This solution was prepared by dissolving $10 \mathrm{mg}$ of metformin hydrochloride in $100 \mathrm{ml}$ of distilled water in calibrated flask.

\section{Estimation of Absorption Maxima}

The standard solution of metformin hydrochloride $(10 \mu \mathrm{g} / \mathrm{ml})$ was scanned in the range of 200-350 nm which shows maxima located at $232 \mathrm{~nm}$ (Figure 2). Therefore, 232nm wavelength was selected for the construction of calibration curve.

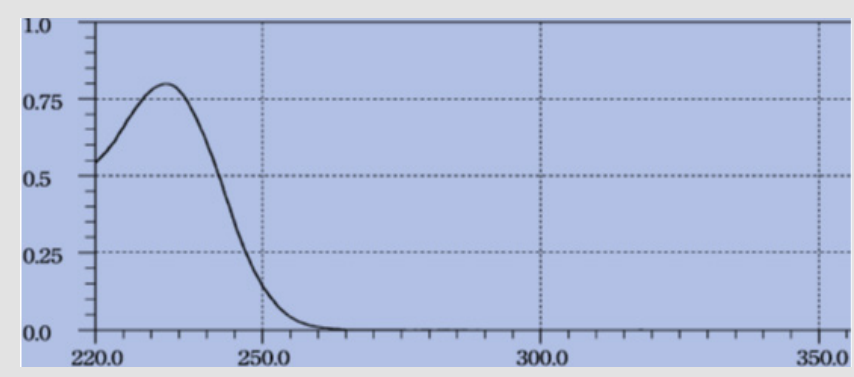

Figure 2: Absorption spectra of $10 \mu \mathrm{g} / \mathrm{ml}$ of metformin hydrochloride against distilled water

\section{Recommended Procedure}

Aliquots of standard solution of metformin hydrochloride (50-400 $\mu$ g) were transferred into a series of $25 \mathrm{ml}$ calibrated flasks,calibration curve was prepared in the concentration range of $2-16 \mu \mathrm{g} / \mathrm{ml}$.The absorbance was measured at $232 \mathrm{~nm}$ against distilled water as a blank .The concentration of the sample solution can be determined by using the calibration curve.

\section{Procedures for Pharmaceutical Preparations (Tablets)}

To minimize a possible variation in the composition of the Tablets were provided from state company of drug industries and medical appliance (NDI) Nineveh - Iraq. Ten tablets were weighed and amount of tablet powder equivalent to $10 \mathrm{mg}$ of metformin hydrochloride was weighed accurately and dissolved in about 80 $\mathrm{ml}$ Distilled water, mixed well for $20 \mathrm{~min}$ and then filtered. The filtrate was made up to $100 \mathrm{~mL}$ with Distilled water and aliquot of this solution was treated as described above for recommended procedure and the concentration was calculated by using the calibration curve of this method.

\section{Procedure for Water Samples}

Distilled and tap water samples $(100 \mathrm{ml})$ were fortified with $10 \mathrm{mg}$ of metformin hydrochloride. The fortified water samples were analyzed as desired under general procedure.

\section{Results and Discussion}

UV- Visible spectrophotometry is still considered to be a convenient and low-cost method for the estimation of pharmaceuticals [18-20]. This method used for the estimation of metformin hydrochloride in pharmaceutical preparations and environmental wastewater samples was found to be sensitive, simple, accurate,and reproducible.Beer s law was obeyed in the concentration range of $2-16 \mu \mathrm{g} / \mathrm{ml}$ Figure 3 with correlation coefficient of 0.998 , intercept of 0.0258 and slope of 0.0773 . The conditional molar absorptivity was found to be1.28x104 l/ mol.cm.The accuracy and precision of the method, a pure drug solution was analyzed at three different concentrations, each estimation being repeated six times. The relative error (\%) and relative standard deviation values are summarized in Table 1.From Table 1 the values of standard deviation were satisfactory, and the recovery studies were close to $100 \%$. The RSD\% value is less than 1.8 indicative of accuracy of the method.

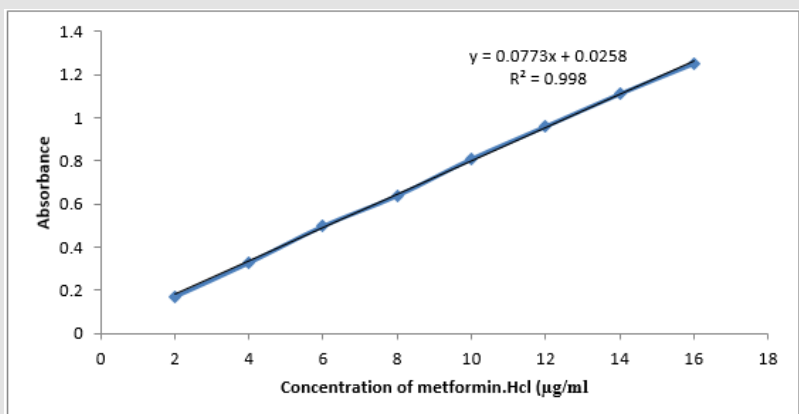

Figure 3: Calibration curve for metformin hydrochloride

Table 1: Accuracy and precision of the proposed method

\begin{tabular}{|c|c|c|}
\hline $\begin{array}{c}\text { Metformin hydrochloride taken } \\
(\boldsymbol{\mu g} / \mathbf{m l}) \mathbf{)}\end{array}$ & $\operatorname{Er}(\%)$ a & RSD (\%) \\
\hline 4 & 1 & 1.7 \\
\hline 10 & 0.9 & 1.6 \\
\hline 61 & 0.95 & 1.4 \\
\hline
\end{tabular}

\section{Analytical Application}

The proposed method was satisfactorily applied to the estimation of metformin hydrochloride in its pharmaceutical 
preparation'stablets.The results of the assay of the pharmaceutical preparations revels thatthere is close agreement between the results obtained by the proposed method and the label claim. as cited in Tables $2 \& 3$

Table 2: Determination of metformin hydrochloride in tablets formulations

\begin{tabular}{|c|c|c|c|}
\hline $\begin{array}{c}\text { Pharmaceutical } \\
\text { formulations }\end{array}$ & $\begin{array}{c}\text { Label } \\
\text { amount(mg) }\end{array}$ & $\begin{array}{c}\text { Found by } \\
\text { proposed } \\
\text { method(mg) }\end{array}$ & Recovery\% \\
\hline $\begin{array}{c}\text { Glucosam tablets } \\
\text { (NDI-Iraq) }\end{array}$ & $500 \mathrm{mg} / \mathrm{tab}$ & 499.85 & 99.97 \\
\cline { 2 - 4 } & $850 \mathrm{mg} / \mathrm{tab}$ & 851.25 & 100.147 \\
\hline $\begin{array}{c}\text { METFORMAL } \\
\text { (SPA-Italy) }\end{array}$ & $500 \mathrm{mg} / \mathrm{tab}$ & 499.4 & 99.88 \\
\hline
\end{tabular}

*mean value of ten determinations

Table 3: Determination of metformin hydrochloride in environmental water samples

\begin{tabular}{|c|c|c|c|}
\hline \multirow{3}{*}{ Water samples } & \multicolumn{2}{|c|}{$\begin{array}{c}\text { Metformin hydrochloride }(\boldsymbol{\mu g} / \\
\mathbf{m l} \boldsymbol{*}^{*}\end{array}$} & $\begin{array}{c}\text { \% } \\
\text { Recovery(n=10) }\end{array}$ \\
\cline { 2 - 4 } & Found & Taken & 99.5 \\
\hline \multirow{3}{*}{ Tap water } & 4 & 3.98 & 100.2 \\
\cline { 2 - 4 } & 10 & 10.02 & 99.25 \\
\cline { 2 - 4 } & 16 & 15.88 & 99.75 \\
\hline \multirow{3}{*}{ River water } & 4 & 3.99 & 99.5 \\
\cline { 2 - 4 } & 10 & 9.95 & 100 \\
\cline { 2 - 4 } & 16 & 16 & \\
\hline
\end{tabular}

*Mean of ten determination

\section{Application of the Proposed Method to Content Uniformity [21-23]}

Content uniformity or the Uniformity of dosage unit was defined as the degree of uniformity in the amount of active substance among dosage units. The risk assessment strategy underlying content uniformity testing is the assumption that some pre-specified limits exist where safety and efficacy outcomes may change if content uniformity fails. The proposed method proved to be suitable for the content uniformity test, where a great number of assays on individual tablets are required. Data presented in Table 4 indicate that the proposed method cans accurately and precisely quantitative metformin hydrochloride in its commercially available tablets. The mean percentage (with RSD) of the labeled claim found in ten tablets was $100.25(0.64 \%)$ which fall within the content uniformity limits specified by the United State Pharmacopeia [22].

Table 4: Content uniformity testing of tablets using the Proposed method

\begin{tabular}{|c|c|}
\hline Parameter & \% of the label claim \\
\hline Tablet No.1 & 100.6 \\
\hline Tablet No.2 & 99.6 \\
\hline Tablet No.3 & 100.5 \\
\hline
\end{tabular}

\begin{tabular}{|c|c|}
\hline Tablet No.4 & 100.7 \\
\hline Tablet No.5 & 99.9 \\
\hline Tablet No.6 & 100.6 \\
\hline Tablet No.7 & 99.8 \\
\hline Tablet No.8 & 100.8 \\
\hline Tablet No.9 & 100,7 \\
\hline Tablet N0.10 & 99.7 \\
\hline Mean(X) & 100.29 \\
\hline \%RSD & 0.64 \\
\hline Max. allowed unit value [22] & $\pm 15 \%$ \\
\hline
\end{tabular}

\section{Conclusion}

The developed method is found to be highly sensitive, accurate, simple, precise and economical, and can be used for routine quality control analysis of metformin hydrochloride in pure form, pharmaceutical formulations and application to content uniformity testing.

\section{Acknowledgments}

The author (Nief Rahman Ahmed) wishes to express gratitude to his former company [the state company of drug industries and medical appliance (NDI)] (Nineveh - Iraq.) for providing gift sample of metformin hydrochloride standard materials and pharmaceutical preparations (Tablets) and for permission and facilities to carry out the research work.

\section{References}

1. Nief Rahman Ahmed (2012) Facial visible spectrophotometric determination of metformin hydrochloride in glucosam tablets and industrial wastewater: Application to content uniformity testing. Iraqi Journal of Pharmacy 12(1): 75-85.

2. British Pharmacopoeia (2014) HM Stationery office, London, UK 2: 230.

3. British National Formulary (BNF) (2016) Royal Pharmaceutical Society 70: 593-594.

4. Sweet man SC, Editors (2009) Martindale - The Complete Drug Reference. $36^{\text {th }}$ Edn. London: Pharmaceutical Press p. 453.

5. British Pharmacopoeia (2010) HM Stationery office, London, UK.

6. Nief Rahman Ahmed (2012) Spectrophotometric determination of metformin in pharmaceutical preparation (tablets) and environmental water samples: Application to content uniformity testing. Iraqi National J Chem 47: 300-310.

7. Nief Rahman Ahmed, Farha Khalaf Omar (2012) Spectrophotometric determination of metformin hydrochloride via oxidative coupling reaction with 1-naphthol in pharmaceutical and environmental water sample. Iraqi National J of Chem 46: 161-170.

8. Sowjanya P (2015) RP-HPLC method development of metformin in pharmaceutical dosage form. Research and Reviews: J Pharm Analysis 4(4): 9-20.

9. Tache F, Albu M (2007) Specificity of an Analytical HPLC Assay Method of Metformin Hydrochloride. Revue Roumaine De Chimie 52(6): 603-609.

10. Abo-dan M, Shour S, Abo dan H (2001) Conduct metric titration of metformin in pure form and in pharmaceutical preparations using sodium-tetra phenyl borate and acetyl pyridinium bromide. Asian J Chem 13: 1-7. 
11. Wang Z, Zhang Z, Wf L, Zhang X (2003) Sensitive flow-injection chemiluminescence determination of metformin based on N-bromosuccinimide-fluorescein system. Anal Lett 36: 2683- 2697.

12. Karine L, Santos M, Lima C (2005) A catalytic multi-pumping flow system for chemiluminometric determination of metformin. Anal Bioanal Chem 382(2): 452-457.

13. Chao H, Zhang Z, Deyong H and Xiong Y (2006) Chemiluminescence determination of metformin based on hydroxyl radical reaction and molecularly imprinted polymer on- line enrichment. Anal Bioanal Chem 385: 128-133.

14. Edward P, Shery F (2006) Non-aqueous capillary electrophoresis for the determination of metformin, phenformin and glyburide in human plasma. Journal of chromatogr B 843(1): 94-99.

15. Dobaria N, Shan S, Rajput S (2006) Development of novel plastic membrane ion - selective electrode for metformin hydrochloride. Indian J Pharm Sci 68(5): 562-565.

16. Slawomira S, Valentine M, Witold C, Adam S, Robert Z (2007) Direct determination of metformin in urine by adsorptive catalytic squarewave voltammetry. J Pharm Biomed Anal 45(2): 275-281.

17. The United State Pharmacopeia (USP) (2009) Convention P. 2905.

ISSN: 2574-1241

DOI: $10.26717 /$ BJSTR.2020.30.004959

Nief Rahman Ahmed. Biomed J Sci \& Tech Res

(c) (P) This work is licensed under Creative

Submission Link: https://biomedres.us/submit-manuscript.php
18. Nief Rahman Ahmed (2014) Ultraviolet Spectrophotometric Estimation of Trifluoperazine. Hcl in Pharmaceutical Preparations and Environmental Wastewater Samples: Application to Content Uniformity Testing. Research \& Reviews: J Pharm Anal 3(2): 30-34.

19. Nief Rahman Ahmed (2013) A sensitive spectrophotometric estimation of tadalafil in pharmaceutical preparations and industrial wastewater samples. J Baghdad for Sci 10(3): 1005-1013.

20. Nief Rahman Ahmed, Husam Waleed Yaseen (2018) Ultraviolet Estimation of Guaiphenesin in Pharmaceutical Preparations and Environmental Wastewater Samples. Res J Pharm Biol Chem Sci 9(4): $39-45$.

21. Nief Rahman Ahmad, Wael A Al-Qazzaz (2019) Spectrophotometric Estimation of Thiamine in Tablet form Application to Content Uniformity Testing. Raf J Sci 28(2): 146-151.

22. The United State Pharmacopeia (USP) (2010) Convection, Inc,33-NF, 28 p. 418.

23. Nief Rahman Ahmed (2017) High Performance Liquid Chromatographic Method for the Determination of Chlordiazepoxide in Pharmaceutical Preparations Application to content uniformity testing. Al-Mustansiriyah J Pharm Sci 17(2): 54-51.

$\begin{array}{ll}\text { BIOMEDICAL } & \text { Assets of Publishing with us } \\ \text { RESEARCHES } & \text { - Global archiving of articles } \\ \text { - Immediate, unrestricted online access } & \text { - Rigorous Peer Review Process } \\ & \text { - Authors Retain Copyrights } \\ \end{array}$

